\title{
Kajian Pustaka: Penerapan Balanced Scorecard (BSC) dalam Analisis Kinerja Rumah Sakit di Berbagai Negara
}

\section{Literature Review: Application of Balanced Scorecard (BSC) in Hospital Performance Analysis in Various Countries}

\author{
Grahyta Dhamayanti ${ }^{1}$, Wahyu Sulistiadi ${ }^{2}$ \\ ${ }^{1}$ Program Sarjana Manajemen Informasi Kesehatan, Departemen Biostatistik dan Kependudukan, \\ Fakultas Kesehatan Masyarakat, Universitas Indonesia \\ ${ }^{2}$ Departemen Administrasi dan Kebijakan Kesehatan, Fakultas Kesehatan Masyarakat, Universitas \\ Indonesia \\ Email: grahyta.dhamayanti71@ui.ac.id
}

\begin{abstract}
Abstrak
Latar Belakang: Balance scorecard (BSC) digunakan sebagai alat pengambilan keputusan mengenai tindakan-tindakan yang harus dilakukan untuk memperbaiki kekurangan dan memajukan rumah sakit. Tujuan: Penelitian ini bertujuan untuk mengetahui penerapan balanced scorecard (BSC) dalam analisis kinerja rumah sakit di berbagai negara. Metode: Penelitian ini menggunakan metode kajian pustaka. Hasil: Hasil kajian pustaka pada tujuh jurnal menunjukkan bahwa semua menyimpulkan lokalisasi dan penggunaan konseptual BSC dapat sangat meningkatkan kinerja rumah sakit. Hasil analisis kinerja dengan BSC di rumah sakit juga dapat memberikan arahan yang jelas dalam menentukan kebijakan, sumber daya, dan kegiatan rutin, serta dalam membangun sistem di setiap unit yang ada di rumah sakit. Kesimpulan: BSC tidak hanya dapat diterapkan di rumah sakit swasta, namum rumah sakit pemerintah juga perlu menerapkan BSC untuk mengukur kinerjanya dan digunakan sebagai pedoman dalam membuat kebijakan dan desain atau rencana kerja. Temuan pada penelitianpenelitian yang sudah ada juga harus diperkaya dengan literatur dan dengan bukti empiris tentang manfaat aplikasi BSC di rumah sakit. Hal tersebut juga akan memberikan pengalaman bagi sejumlah negara di dunia yang dapat menjadi referensi untuk memperluas implementasi BSC dalam administrasi rumah sakit.
\end{abstract}

Kata Kunci: analisis; kinerja; organisasi kesehatan; rumah sakit; balance score card.

\begin{abstract}
Background: Balance scorecard (BSC) is used as a decision-making tool regarding the actions that must be taken for improving limitation and advancing the health organization. Objective: This study aims to determine the application of the balanced scorecard (BSC) in hospital performance analysis in various countries. Method: This study uses the literature review method. Results: The results of the literature review in seven journals show that all concluding localization and conceptual use of BSC can greatly improve hospital performance. The results of the application of BSC in hospital performance analysis can also provide clear direction in determining policies, resources, and routine activities, as well as in building systems in every unit in the hospital. Conclusions: BSC can not only be applied in private hospitals, but public hospitals also need to apply BSC to measure its performance and be used as a guideline in making policies and designs. The findings in existing studies must also be enriched with literature and with empirical evidence of the benefits of BSC application in hospitals. It will also provide experience for a number of countries in the world that can be a reference for expanding the BSC implementation in hospital administration.
\end{abstract}

Keyword: analysis; performance; health organization; hospital; balance score card. 


\section{LATAR BELAKANG}

Fasilitas pelayanan kesehatan merupakan satu di antara organisasi-organisasi kesehatan yang sudah lama berkembang di dunia. Institusi ini juga merupakan organisasi kesehatan yang memiliki pendapatan tinggi dalam bidang jasa yang diberikan ${ }^{1}$. Rumah sakit merupakan bagian dari fasilitas pelayanan kesehatan. Bedasarkan definisinya rumah sakit diartikan ke dalam tiga kelompok yaitu rumah sakit, rumah sakit umum, dan rumah sakit khusus. Pengertian rumah sakit secara umum adalah institusi yang menyediakan pelayanan kesehatan meliputi pelayanan rawat inap, rawat jalan, dan gawat darurat. Sedangkan pengertian rumah sakit umum dan khusus dibedakan bedasarkan bidang pelayanan yang disediakan oleh rumah sakit ${ }^{2}$.

Rumah sakit tidak hanya dituntut untuk memberikan pelayanan kesehatan, namun rumah sakit juga dituntut untuk memiliki kualitas pelayanan kesehatan yang baik. Kualitas pelayanan rumah sakit mencerminkan mutu dari rumah sakit tersebut ${ }^{3}$. Hal ini yang akan memberikan citra baik untuk rumah sakit dalam memberikan hak pelayanan yang memuaskan kepada konsumen. Kepuasan merupakan tujuan inti dari berdiri dan berkembangnya suatu organisasi. Karena dengan hal ini mereka akan tetap ada dan dibutuhkan ${ }^{4}$.

Penjelasan tersebut selaras dengan misi SDG nomor empat yang bertuliskan Health Service Delivery and Organization. Pada tujuan ini fasilitas pelayanan dituntut untuk menyediakan pelayanan yang efisien dan berkualitas tinggi, terjangkau, dan terintegrasi. Pemerintah yang berkontribusi juga harus mengadopsi kebijakan yang mencakup kinerja seluruh sektor. Rumah sakit juga adalah sektor ekonomi utama bagi suatu negara. Bedasarkan data agregat rumah sakit menyumbangkan pendapatan bagi kemajuan ekonomi dunia sekitar US $\$ 5,8$ triliun per tahun ${ }^{5}$. Kendati demikian, sejumlah permasalahan mengenai kualitas rumah sakit yang buruk masih terjadi. Sehingga hal ini akan menghambat perkembangan dan kemajuan rumah sakit tersebut.

Masalah utama yang menghambat rumah sakit membuat kemajuan yang memuaskan dalam kinerja dan produktivitas sistem adalah budaya, organisasi dan praktik manajerial. Hal ini tidak konsisten dengan bisnis yang kompetitif, termasuk praktik yang beroperasi tidak didorong oleh biaya atau keuangan yang baik. Adapun beberapa alasan spesifik mengapa rumah sakit belum aktif atau sukses di bidang ini disebabkan oleh pegawai rumah sakit yang memiliki sedikit pengalaman terhadap 
lingkungan yang kompetitif, kurangnya partisipasi karyawan, terutama di kalangan dokter, dan Layanan yang diberikan sulit diukur ${ }^{6}$. Oleh sebab itu beberapa alat analisis kinerja dicipakan untuk mengatasi masalah-masalah tersebut.

Satu di antara alat-alat untuk menganalisis kinerja adalah Balance Scorecard (BSC). Balanced scorecard (BSC) adalah teknik yang banyak digunakan untuk mengukur kinerja suatu organisasi. Inti dasar BSC dipandu oleh visi dan strategi organisasi, yang merupakan dasar untuk pembentukan empat perspektif $\mathrm{BSC}^{7}$. Sejumlah literatur menyebutkan bahwa BSC merupakan alat manajemen kinerja yang menganalisis dari bidang keuangan dengan mempertimbangkan preferensi pelanggan, proses internal terdiri dari efektivitas dan efisiensi, serta pembelajaran dan pertumbuhan $^{8}$. Oleh sebab itu BSC selain digunakan sebagai mengevaluasi dan mengukur kinerja organisasi, BSC juga digunakan sebagai alat pengambilan keputusan mengenai tindakan-tindakan yang harus dilakukan untuk memperbaiki kekurangan dan memajukan organisasi.

Penelitian ini mengkaji tujuh jurnal dari berbagai negara yang telah melewati penyisihan kriteria inklusi dan eksklusi. Pada pembahasan terdapat lima bagian. Bagian pertama menjelaskan pengetian BSC. Bagian kedua menjelaskan latar belakang masingmasing penelitian. Bagian ketiga membahas mengenai hasil penelitian. Bagian keempat membahas keterbatasan masing-masing penelitian dan bagian terakhir memberikan rekomendasi mengenai tindakan yang perlu dilakukan di masa yang akan datang.

\section{TUJUAN}

Penelitian ini bertujuan untuk mengetahui penerapan balanced scorecard (BSC) dalam analisis kinerja rumah sakit di berbagai negara.

\section{METODE}

Kajian pustaka yang membahas penerapan balanced scorecard (BSC) dalam analisis kinerja rumah sakit. Kriteria inklusi jurnal yang digunakan adalah analisis kinerja rumah sakit dengan balance scorecard (BSC), sedangkan kriteria eksklusi adalah jurnal yang ditampilkan tidak full text. Pencarian jurnal terbatas terdiri dari jurnal internasional berbahasa inggris yang diakses dari pencarian internet dari database yaitu: Sciencedirect, Spinger, dan Proquest dengan kata kunci balance scorecard in 
hospital. Jurnal yang memenuhi kriteria inklusi dikumpulkan dan diperiksa secara sistematis. Pencarian literature yang dipublikasikan dari berada dalam 10 tahun terakhir yaitu dari tahun 2010 sampai dengan 2019.

\section{HASIL}

Pencarian terhadap sejumlah literature yang membahas mengenai penerapan balanced scorecard (BSC) dalam analisis kinerja rumah sakit pada database yang ada di situs Sciencedirect, Spinger, dan Proquest. Pada ketiga database tersebut didapatkan hasil sebanyak lebih dari seratus jurnal yang berhubungan dengan kata kunci "balance scorecard in hospital". Namun hanya ada tujuh jurnal yang masuk ke dalam kriteria inklusi dan eksklusi pada penelitian ini. Berikut merupakan daftar jurnal terpilih bedasarkan kriteria inklusi dan eksklusi:

Tabel 1. Deskripsi Penelitian Terpilih

\begin{tabular}{|c|c|c|c|}
\hline Judul & Peneliti & Tahun & Negara \\
\hline $\begin{array}{l}\text { Understanding the context of Balanced } \\
\text { Scorecard Implementation: a hospital-based } \\
\text { case study in Pakistan }{ }^{9}\end{array}$ & Rabbani & 2011 & Pakistan \\
\hline $\begin{array}{l}\text { Application of the balanced scorecard to an } \\
\text { academic medical center in Taiwan: The } \\
\text { effect of warning systems on improvement of } \\
\text { hospital performance }\end{array}$ & Chen & 2012 & Taiwan \\
\hline $\begin{array}{l}\text { Ontario Hospitals are not Using Palliative } \\
\text { Care Performance Indicators in Their } \\
\text { Balanced Scorecards }{ }^{11}\end{array}$ & Weiss & 2013 & Canada \\
\hline $\begin{array}{l}\text { Performance outcomes of balanced scorecard } \\
\text { application in hospital administration in } \\
\text { China }^{12}\end{array}$ & Lin & 2014 & Cina \\
\hline $\begin{array}{l}\text { Strategic Value of Cloud Computing in } \\
\text { Healthcare organizations using the Balanced } \\
\text { Scorecard Approach: A case study from A } \\
\text { Saudi Hospital }{ }^{13}\end{array}$ & Alharbi & 2016 & $\begin{array}{l}\text { Saudi } \\
\text { Arabia }\end{array}$ \\
\hline $\begin{array}{l}\text { Balanced Scorecard Approach to Determine } \\
\text { Accreditation Measures with Clinical } \\
\text { Governance Orientation: A Case Study of } \\
\text { Sarem Women's Hospital }{ }^{14}\end{array}$ & Kazemi & 2016 & Iran \\
\hline $\begin{array}{l}\text { Balanced performance measurement in } \\
\text { research hospitals: the participative case } \\
\text { study of a haematology department }{ }^{15}\end{array}$ & Catuogno & 2017 & Italia \\
\hline
\end{tabular}




\section{PEMBAHASAN}

Rumah sakit merupakan satu di antara organisasi di bidang kesehatan. Organisasi adalah suatu entitas sosial yang terdiri dari sekelompok tim dan secara sadar mengkoordinasikan pekerjannya dengan terus menerus untuk mencapai satu tujuan organisasi dengan batasan yang relatif dapat diidentifikasikan ${ }^{16}$. Tujuan organisasi dapat dicapai melalui visi dan misi organisasi. Selain itu organisasi juga membutuhkan gambaran kinerja organisasi agar organisasi tersebut dapat mengetahui keberhasilan dari tujuan dan sasaran yang ingin dicapai. Gambaran kinerja memerlukan pengukuran dan dari pengukuran ini akan memberikan arahan kepada organisasi dalam mengambil langkah selanjutnya termasuk evaluasi dan rencana kerja ${ }^{17}$. Terdapat beberapa alat pengukuran untuk menggambarkan kinerja organisasi, satu di antaranya adalah Balanced scorecard (BSC). Balanced scorecard (BSC) dianggap sebagai alat yang berguna untuk manajemen di berbagai lingkungan bisnis ${ }^{10}$. Banyak perusahaan perawatan kesehatan menciptakan balanced scorecard (BSC) untuk menggambarkan indikator kinerja dengan prioritas tinggi dan untuk mengukur keberhasilan rencana peningkatan kualitas organisasi termasuk rumah sakit ${ }^{11}$.

Balanced scorecard (BSC) terdiri dari dua kata yaitu Balanced (seimbang) dan Scorecard (kartu skor). Balanced (seimbang) menunjukkan bahwa kinerja anggota kelompok organisasi diukur secara seimbang dan dipandang dari dua aspek yaitu keuangan dan non keuangan, jangka pendek dan jangka panjang dan dari segi intern maupun ekstern. Sedangkan scorecard (kartu skor) merupakan kartu yang digunakan untuk mencatat skor hasil kinerja seseorang yang nantinya digunakan untuk membandingkan dengan hasil kinerja yang sesungguhnya ${ }^{18}$. Sehingga balanced scorecard (BSC) adalah alat manajemen strategis yang sangat penting yang dapat membantu organisasi, tidak hanya untuk mengukur kinerjanya namun juga untuk menentukan kebijakan atau strategi dalam pencapaian tujuan organisasinya ${ }^{19}$.

Terdapat empat perspektif dalam BSC yaitu keuangan, pelanggan, bisnis internal, serta pembelajaran dan pertumbuhan. Pada perspektif keuangan mengukur kinerja ekonomu, efisiensi, dan efektivitas organisasi. Perspektif pelanggan memiliki lima dimensi antara lain bukti fisik, kehandalan, daya tanggap, jaminan, dan perhatian. Sedangkan perspektif bisnis internal memiliki tiga dimensi yaitu fasilitas, sumber daya 
manusia (SDM), dan proses. Terakhir untuk perspektif pembelajaran dan pertumbuhan memiliki dua dimensi yaitu dimensi kemampuan dan dimensi motivasi ${ }^{19}$.

Sejumlah jurnal yang diteliti memiliki perbedaan masing-masing dalam membahas analisis kinerja dengan BSC di rumah sakit. Secara garis besar pada sejumlah penelitian menggunakan analisis BSC di rumah sakit untuk membandingkan antara teori dan pelaksanaan atau kondisi nyata di lapangan pada organisasi kesehatan (rumah sakit). Hal itu juga dilakukan untuk mempelajari indeks akreditasi, pilar tata kelola klinis, dan perspektif balanced scorecard untuk mencapai konsep yang mudah dimengerti, dapat dieksekusi, dan terpadu untuk indeks yang digunakan untuk mengevaluasi kinerja di sektor kesehatan ${ }^{14}$. Dari segi manajemen penelitian yang dilakukan dilatarbelakangi dengan tujuan untuk meninjau, merancang dan menerapkan sistem pengukuran kinerja multidimensi yang dapat membantu pemangku kepentingan di rumah sakit dalam mengambil keputusan ${ }^{15}$. Adapula penelitian yang menggabungkan antara dua model analisis kinerja untuk mengetahui bagaimana pengimplementasian alat-alat analisis kinerja tersebut. Hal tersebut untuk mendapatkan rekomendasi peluang dan tantangan dalam implementasi BSC di rumah sakit ${ }^{9,10}$. Penelitian lain juga menyebutkan bahwa analisis BSC yang dilakukan bertujuan untuk mengukur kualitas kinerja rumah sakit dan dampaknya terhadap kinerja rumah sakit ${ }^{11,12}$. Tidak hanya menganalisis kinerja rumah sakit secara umum, namun ada pula penelitian yang menganalisis kinerja secara rinci yaitu terhadap unit yang ada di rumah sakit (Teknologi Informasi RS) ${ }^{13}$.

Hasil yang diperoleh setiap penelitian berbeda-beda. Penelitian di Canada menunjukkan terdapat $16 \%$ rumah sakit menggunakan analisis kinerja dengan BCS di rumah sakit ${ }^{11}$. Berbeda dengan yang ada di Cina bahwa sebagian besar rumah sakit umum Cina telah mengadopsi BSC dalam administrasi rumah sakit. BSC berkontribusi pada peningkatan kinerja organisasi dan pribadi, serta efek kontribusi tersebut meningkat seiring dengan tingkat (level) pengimplementasian BSC. Dampak positif lain dari BSC pada kinerja rumah sakit dipengaruhi oleh faktor-faktor lingkup/skala operasional, kualitas teknologi (peringkat) dan kelengkapan sumber daya medis yang dilengkapi oleh rumah sakit ${ }^{12}$. Penelitian di Pakistan menunjukkan hasil pengimplementasian BSC untuk mengalanisis kinerja rumah sakit memberikan arahan yang jelas dalam menentukan kebijakan, sumber daya, dan kegiatan rutin ${ }^{9}$. Di Taiwan 
analisis kinerja di rumah sakit dengan BSC menjadi alat yang efektif dan efisien bila dijalankan dengan penuh perhatian dan berkelanjutan, serta konsisten dalam upaya untuk mengelola perawatan medis dan kontrol biaya yang lebih baik ${ }^{10}$. Di Iran, BSC memfasilitasi penerapan akreditasi di rumah sakit ${ }^{14}$. Semua jurnal yang ditinjau setuju bahwa lokalisasi dan penggunaan konseptual BSC juga dapat sangat meningkatkan kinerja rumah sakit ${ }^{14,15}$. Berbeda dengan penelitian di rumah sakit Arab Saudi yang menggunakan analisis BSC untuk pengambilan keputusan dalam menggunakan sistem Cloud Computing pada sistem informasinya. Namun hasil yang diperoleh dari BSC menunjukkan bahwa sistem tersebut memenuhi nilai strategis untuk semua perspektif dengan beberapa harapan tinggi untuk perspektif keuangan ${ }^{13}$.

Di antara tujuh jurnal yang ditinjau, tidak semua menyampaikan keterbatasan dari penelitian mereka. Hanya ada dua jurnal yang menjelaskan keterbatasan penelitian yaitu jurnal dari Pakistan dan Taiwan. Pada penelitian di Pakistan, penelitian hanya dilakukan di satu rumah sakit akademik swasta. Karena peneliti mengungkapkan setidaknya ada lima rumah sakit swasta lainnya di negara ini yang dapat dibandingkan dengan rumah sakit yang diteliti dalam hal tenaga terampil, fasilitas diagnostik dan kuratif, dan infrastruktur teknologi informasi ${ }^{9}$. Sedangkan keterbatasan penelitian di Taiwan mengungkankan bahwa penelitian mencakup rumah sakit yang mungkin tidak benarbenar menggunakan analisis kinerja untuk mengatasi permasalahan kinerja di rumah sakit tersebut ${ }^{11}$.

Rekomendasi yang diberikan dari masing-masing penelitian menyatakan bahwa dalam menerapkan BSC dalam pengaturan rumah sakit perlu memastikan budaya partisipatif, mandat kelembagaan yang jelas, dukungan kepemimpinan yang tepat, dan sistem penghargaan yang tepat, serta kepekaan terhadap manfaat BSC $^{9}$. Sistem informasi rumah sakit sebenarnya dapat digunakan untuk memberikan bantuan beragam aspek kepada manajer rumah sakit dan BSC merupakan alat yang efektif dalam pengelolaan kinerja, dan bisa juga dianggap sebagai sistem peringatan dini. Situasi saat ini juga telah membuktikan bahwa sistem peringatan semacam itu memang memiliki kegunaan, dan dapat meningkatkan indikator kinerja rumah sakit ${ }^{10}$. Pada penelitian di Cina merekomendasikan bahwa temuan pada penelitian-penelitian yang sudah dilakukan harus diperkaya dengan literatur yang ada dan dengan bukti empiris tentang manfaat aplikasi BSC dalam industri perawatan kesehatan. Hal tersebut juga akan 
memberikan pengalaman bagi sejumlah negara di dunia yang dapat menjadi referensi untuk memperluas implementasi BSC dalam administrasi rumah sakit ${ }^{12}$. Penelitian di Iran merekomendasikan analisis kinerja dengan BSC digunakan di rumah sakit swasta. Implementasi model ini membutuhkan pengukuran indeks, menentukan tujuan dan langkah-langkah yang diperlukan untuk peningkatan perbaikan rumah sakit, dan akhirnya mencetak indeks. Mengingat modelnya fleksibel, dapat disesuaikan berdasarkan persyaratan masing-masing unit ${ }^{14}$. Namun tidak hanya di rumah sakit swasta pada penelitian di Itali menyatakan bahwa pembuat kebijakan harus menyediakan rumah sakit dengan pedoman pemerintah yang dapat mendukung desain dan adopsi $\mathrm{BSC}^{15}$.

\section{KESIMPULAN}

Hasil kajian pustaka pada tujuh jurnal menunjukkan bahwa semua menyimpulkan lokalisasi dan penggunaan konseptual BSC dapat sangat meningkatkan kinerja rumah sakit. Hasil analisis kinerja dengan BSC di rumah sakit juga dapat memberikan arahan yang jelas dalam menentukan kebijakan, sumber daya, dan kegiatan rutin, serta dalam membangun sistem di setiap unit yang ada di rumah sakit. BSC tidak hanya dapat diterapkan di rumah sakit swasta, namum rumah sakit pemerintah juga perlu mengimplementasikan BSC untuk mengukur kinerjanya dan digunakan sebagai pedoman dalam membuat kebijakan dan desain atau rencana kerja. Temuan pada penelitian-penelitian yang sudah ada juga harus diperkaya dengan literatur dan dengan bukti empiris tentang manfaat aplikasi BSC di rumah sakit. Hal tersebut juga akan memberikan pengalaman bagi sejumlah negara di dunia yang dapat menjadi referensi untuk memperluas implementasi BSC dalam administrasi rumah sakit.

\section{UCAPAN TERIMA KASIH}

Penelitian ini didukung oleh Dr. drg. Wachyu Sulistiadi M.A.R.S. selaku dosen pengampu mata kuliah Perencanaan, Pemantauan, dan Penilaian Program Kesehatan. 


\section{DAFTAR PUSTAKA}

1. Shukri, NFM. Organizational Structure and Performances of Responsible Malaysian Healthcare Providers: A Balanced Scorecard Perspective. Malaysia: Procedia Economics and Finance 28. 2015. 202 - 212.

2. Republik Indonesia. Peraturan Menteri Kesehatan Republik Indonesia Nomor 56 Tahun 2014 tentang Klasifikasi dan Perizinan Rumah Sakit. Indonesia: Kementerian Kesehatan.

3. Candrasari, M. Analisis Kinerja Keuangan dan Pelayanan dengan Kemandirian Rumah Sakit di RSUD Dr.Abdoer Rahem Situbondo. Jember: Universitas Jember. 2018.

4. Lestari, TRP. Pelayanan Rumah Sakit bagi Masyarakat Miskin (Studi Kasus di Enam Wilayah Indonesia). Indonesia: P usat Pengkajian Pengolah Data dan Informasi Sekretariat Jenderal Dewan Perwakilan Rakyat Republik Indonesia. 2010.

5. WHO. Working for health and growth: investing in the health workforce. Report of the High-Level Commission on Health Employment and Economic Growth. Geneva: WHO. 2016.

6. Behrouzi, F. Applications of the balanced scorecard for strategic management and performance measurement in the health sector. Australia: Australian Health Review. 2014. 38, 208-217.

7. Raeisi, AR. Performance evaluation of Al-Zahra academic medical center based on Iran balanced scorecard model. Iran: J Edu Health Promot. 2012. 1:1.

8. Porporato, M. Do hospital balanced scorecard measures reflect cause-effect relationships? International Journal of Productivity and Performance Management. 2017. Vol. 66 No. 3.

9. Rabbani, F. Understanding the context of Balanced Scorecard Implementation: a hospital-based case study in Pakistan. UK: BioMed Central Ltd. 2011.

10. Chen, H. Application of the balanced scorecard to an academic medical center in Taiwan: The effect of warning systems on improvement of hospital performance. Cina: Journal of the Chinese Medical Association 75. 2012. 530-535 
11. Weiss, A. Ontario Hospitals are not Using Palliative Care Performance Indicators in Their Balanced Scorecards. Canada: Journal of Pain and Symptom Management. 2013. Vol. 46 No. 2.

12. Lin, Z. Performance outcomes of balanced scorecard application in hospital administration in China. Cina: China Economic Review 30. 2014. 1-15

13. Alharbi, F. Strategic Value of Cloud Computing in Healthcare organizations using the Balanced Scorecard Approach: A case study from A Saudi Hospital. Procedia Computer Science 98. 2016. 332 - 339.

14. Kazemi, A. Balanced Scorecard Approach to Determine Accreditation Measures with Clinical Governance Orientation: A Case Study of Sarem Women's Hospital. Iran: Islamic Azad University. 2016.

15. Catuogno, S. Balanced performance measurement in research hospitals: the participative case study of a haematology department. UK: BMC Health Services Research. 2017. 17:522.

16. Musfialdy. Organisasi dan Komunikasi Organisasi. Riau: Universitas Islam Negeri Sultan Syarif Kasim Riau. 2012.

17. Handayani, Bestari Dwi. 2011. Pengukuran Kinerja Organisasi Dengan Pendekatan Balanced Scorecard Pada RSUD Kabupaten Kebumen. Jurnal Dinamika Manajemen: Fakultas Ekonomi Universitas Negeri Semarang.

18. Febriyanti, Diana. 2016. Analisis Kinerja Rumah Sakit Dengan Pendekatan Balanced Scorecard: Studi Kasus di RSUD Wonosari. Fakultas Ekonomi: Universitas Sanata Dharma Yogyakarta.

19. Setyawan, Donie. 2018. Pendekatan Balanced Scorecard Untuk Pengukuran Kinerja Pada Dinas Kesehatan Kabupaten Bondowoso. Fakultas Ekonomi dan Bisnis: Universitas Jember. 